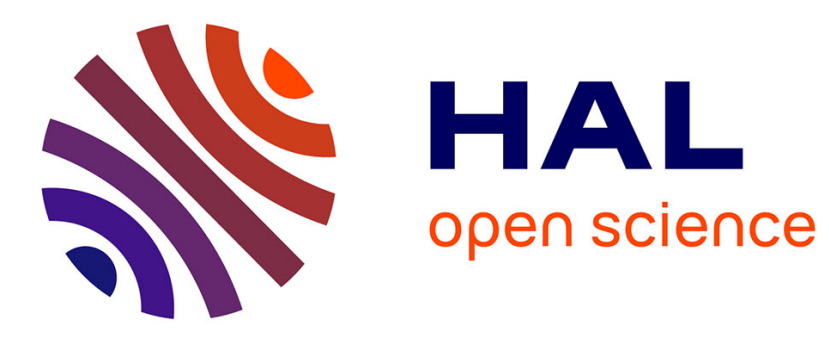

\title{
A cost function for the natural gas transmission industry: further considerations
}

\author{
Olivier Massol
}

\section{To cite this version:}

Olivier Massol. A cost function for the natural gas transmission industry: further considerations: Cahiers de l'Economie, Série Recherche, n 75. 2009. hal-02469553

\section{HAL Id: hal-02469553 \\ https://hal-ifp.archives-ouvertes.fr/hal-02469553}

Preprint submitted on 6 Feb 2020

HAL is a multi-disciplinary open access archive for the deposit and dissemination of scientific research documents, whether they are published or not. The documents may come from teaching and research institutions in France or abroad, or from public or private research centers.
L'archive ouverte pluridisciplinaire HAL, est destinée au dépôt et à la diffusion de documents scientifiques de niveau recherche, publiés ou non, émanant des établissements d'enseignement et de recherche français ou étrangers, des laboratoires publics ou privés. 


\title{
A cost function for the natural gas transmission industry: further considerations
}

\author{
Olivier MASSOL
}

Septembre 2009

\section{Les cahiers de l'économie - $\mathbf{n}^{\circ} 75$}

\author{
Série Recherche
}

olivier.massol@ifp.fr

La collection "Les cahiers de l'économie" a pour objectif de présenter des travaux réalisés à l'IFP et à l'IFP School, travaux de recherche ou notes de synthèse en économie, finance et gestion. La forme peut être encore provisoire, afin de susciter des échanges de points de vue sur les sujets abordés.

Les opinions émises dans les textes publiés dans cette collection doivent être considérées comme propres à leurs auteurs et ne reflètent pas nécessairement le point de vue de l'IFP ou de l'IFP School.

Pour toute information sur le contenu, prière de contacter directement l'auteur.

Pour toute information complémentaire, prière de contacter le Centre Économie et Gestion: Tél. 0147527227 



\title{
A cost function for the natural gas transmission industry:
}

\author{
further considerations
}

Olivier MASSOL

\begin{abstract}
This article studies the cost function for the natural gas transmission industry. 60 years ago, Hollis B. Chenery published an important contribution that demonstrated how, in that particular industry, the production function of microeconomic theory can be rewritten with engineering variables (Chenery, 1949). In 2008, an article published in The Engineering Economist (Yépez, 2008) provided a refreshing revival on Chenery's seminal thoughts. In addition to a tribute to the late H.B. Chenery, this document offers some further comments and extensions on Yépez (2008). It provides a statistically estimated characterisation of the long-run scale economies and a discussion on the short-run economics of the duplication of existing equipments. As a first extension, we study the optimal design for infrastructure that is planned to transport a seasonally-varying flow of natural gas. The second extension analyzes the optimal degree of excess capacity to be built into a new infrastructure by a firm that expects a random rise in its output during the infrastructure's lifetime.
\end{abstract}

\footnotetext{
* I wish to express my gratitude to Ibrahim Abada, Axel Pierru and Stephane Tchung-Ming who read preliminary versions and made useful suggestions. I have benefited from discussions with Frederic Lantz, Michael Martens and Élodie SentenacChemin. I am also indebted to Michel Le Breton for having drawn my attention on H.B. Chenery's work. Any remaining errors are my sole responsibility. The views expressed herein are strictly those of the author and do not necessarily reflect those of IFP.
} 


\section{Introduction}

As far as engineering economics is concerned, the year 2009 corresponds to a special anniversary: 60 years ago, a promising $\mathrm{PhD}$ student named Hollis B. Chenery ${ }^{1}$ published a seminal article that illustrated how the production function of microeconomic theory can be rewritten with engineering variables (Chenery, 1949). His goal was to present a rigorous analysis of the cost function of an industry whose total production function consists of several processes which can be combined in varying proportions to produce a given output. As an illustration, he provided an illuminating case study based on the natural gas transmission industry. In this industry, the combination of processes is such that it is possible to increase output by adding more compressors while keeping the same pipeline or, in the long-run, varying simultaneously both parameters. As he has shown, this flexibility is at the origin of the massive scale economies observed in that industry. Despite a considerable early influence in the academic community (e.g.: Smith, 1957, 1959; Thomson et al., 1972), the engineering approach pioneered by Chenery has gradually disappeared from the applied economic literature during the last 30 years. Moreover, it must be acknowledged that, apart rare exceptions (e.g.: Callen, 1978), most of the articles that fuelled the debate associated with the impressive regulatory reforms implemented in the gas industry did not consider this engineering approach. Given the importance of the gas sector to the energy industry, this situation is somehow frustrating.

However, a recent article published in The Engineering Economist (Yépez, 2008) provided a refreshing revival. In addition to the perpetuation of Chenery's method, at least three reasons can be advanced to illustrate the value added by this contribution. Firstly, this paper presents a clear and modernized version of the Chenery's methodology which includes some interesting refinements. In particular: a more recent version of the gas flow equation ${ }^{2}$ and the possibility to deal with a non-steady elevation of the pipeline. Secondly, Dr. Yépez derived a set of formal equations that describe how total, average and marginal costs vary with output in the short run. And last but not least, Dr. Yépez provided a detailed case study based on a Mexican project. As Chenery (1949) only represents the tip of the iceberg, some complements may be needed to shed some light on Chenery's shrewd thoughts on the gas transmission industry.

This article is organized as follows. In the first section, a complete review of the Chenery-Yépez's model aims at offering some eclectic complements. In the second section, an extension of that model is provided to deal with the case of seasonal variations in the volumes of gas to be transported. The influence of these variations on the optimal design of the transmission equipment is discussed.

\footnotetext{
${ }^{1}$ During his subsequent career, Pr. Chenery's research interest moved to development economics. From 1972 to 1982 , he was the World Bank vice president for development policy and played a key role in the definition of the Bank's strategy.

${ }^{2}$ Chenery (1949) was based on the Weymouth equation that is not so appropriate for large gas pipelines.
} 
Investment recommendations are then addressed in the last section to analyze the rationale of a "building ahead the demand behaviour".

\section{1 - A commented review on the Chenery-Yépez approach}

In this first section, three points are successively discussed: the long-run optimal decision, the behaviour of the cost functions in the short-run and an alternative formulation of the long-run optimal design.

\subsection{Long-run economics}

\section{The Chenery-Yépez approach}

Both authors developed a rigorous model-based cost function for the gas transmission industry based on the case of a gas pipeline that runs a given distance $l$ and transports $Q$, a daily flow of natural gas in MMcfd (millions of cubic feet per day) that is assumed to remain steady all along the infrastructure's lifetime. In their model, output and investment decisions are assumed to be taken separately and the estimate of output is supposed to be made prior to the investment decision. This assumption is consistent with industrial practice because in many cases, this flow is an outcome of exogenous negotiations between a natural gas producer and a group of buyers. As far as investment decision is concerned, two engineering variables have to be considered in the long-run: $D$ the inside diameter of the pipe in inches; and the compressor horsepower per million of cubic feet of gas $H$.

As the firm is assumed to have perfect information on the volume of gas to be transported and on the associated revenues, the project's value is maximized by an investment program which minimizes the total cost of production over the period. Since output is assumed to remain steady all along the infrastructure lifetime, the optimum plan minimizes also the annual total costs. For a given volume to transport, the objective of the gas transmission firm is thus to find a technology-compatible combination of inputs $(D, H)$ that minimizes its annual total cost.

A given combination $(D, H)$ is technology-compatible if, and only if, the two following relations simultaneously hold. Firstly, for a given flow rate $Q$ of natural gas, the frictional loss of energy through a pipe (measured as pressure drop between $P_{1}$ the initial pressure and $P_{2}$ the terminal one in psia) is a decreasing function of the diameter $D$ of the pipe. Considering a steady flow of natural gas and assuming: (1) a friction coefficient that is a function of the diameter and (2) a constant and uniform elevation all along the pipeline, this general flow equation is relatively simple (Yépez, 2008): 


$$
Q=\frac{c_{0}}{\sqrt{l}} D^{8 / 3}\left(\left(\frac{P_{1}}{P_{2}}\right)^{2}-1\right)^{1 / 2}
$$

Here, $c_{0}$ is an exogenous constant parameter (cf.: Yépez, 2008) and $l$ is the pipeline length in miles.

Secondly, the power needed to compress natural gas from a given inlet pressure $P_{0}$ to a predefined outlet pressure $P_{1}$ is given by the following empirical expression (Yépez, 2008):

$$
H=c_{1} \cdot\left(R^{\beta}-1\right) Q
$$

Where $R$ is the pressure ratio $P_{1} / P_{0} \geq 1$ and both $c_{1}$ and $\beta$ are dimensionless constant parameters.

Following a simplification initially proposed by Chenery, if the inlet pressure $P_{0}$ is assumed to be equal to the terminal pressure $P_{2}$ at the delivery point and if we assume that the terminal pressure $P_{2}$ corresponds to an exogenous parameter, then the two technological equations presented above can be simplified (by eliminating $R$ ) into a unique engineering production function:

$$
F(D, H, Q)=\frac{l Q^{2}}{c_{0}{ }^{2} D^{16 / 3}}+1-\left(\frac{H}{c_{1} Q}+1\right)^{\frac{2}{\beta}}=0
$$

This production function embodies the key features of the gas transmission industry and clearly suggests the possibility of smooth continuous substitution between pipe diameter and compression horsepower. From a strict technical perspective, the combination of these two capital factors (diameter and compressor horsepower) is such that it is possible to increase output by adding more compressors while keeping the same pipeline or increasing the pipeline diameter while keeping the same design for the compressors.

As far as costs are concerned, two different elements have to be considered. Firstly, the total yearly capital and operating cost per mile is given by $C_{D}(D)$, a smooth function of the inside diameter ${ }^{3} D$. With Dr. Yépez's terminology, $C_{D}(D)$ is equal to $\alpha_{L} \cdot C_{1}(D)+C_{2}(D)$, where $C_{1}(D)$ is the replacement value of line per mile dependent on the diameter; $\alpha_{L}$ is the fixed-cost annual percentage

\footnotetext{
${ }^{3}$ Usually, the wall thickness of the pipe plays also an important role in the total cost of the line. But, following Chenery (1949) and Yépez (2008), we assume that this parameter can be computed as a function of the diameter of the pipe.
} 
charge dependent on the depreciation and real interest rates so that $\alpha_{L} \cdot C_{1}(D)$ gives the annual cost of the line per mile, and $C_{2}(D)$ the annual operation and maintenance cost per mile.

The annual cost of the compressor station $C_{H}(H)$ constitutes the second type of cost. Again: $C_{H}(H)$ is the sum of two smooth functions of $H$ the horsepower: $\alpha_{C} \cdot C_{3}(H)$ and $C_{4}(H)$, where $\alpha_{C}$ is the fixed-cost annual percentage charge dependent on the depreciation and real interest rates, $\mathrm{C}_{3}(H)$ is the replacement value of the compressor station dependent on the installed horsepower capacity and $C_{4}(H)$ is the operation and maintenance cost.

For a rational firm, the objective is to minimize its annual costs and the Chenery-Yépez approach suggests the following cost-minimization programme:

$$
\begin{array}{ll}
\underset{D, H}{\operatorname{Min}} & \operatorname{LRTC}(D, H)=l . C_{D}(D)+C_{H}(H) \\
\text { s.t. } & F(D, H, Q)=0
\end{array}
$$

With the functional specifications and the numerical parameters presented in Yépez (2008), this constrained minimization problem has a unique ${ }^{4}$ solution. The optimal mix of inputs $\left(D^{*}, H^{*}\right)$ can be obtained thanks to the Lagrangian method. The Lagrangian $\mathcal{L}$ for this constrained minimization problem is:

$$
\mathcal{L}(D, H, \lambda)=l . C_{D}(D)+C_{H}(H)+\lambda F(D, H, Q)
$$

And the optimal solution $\left(D^{*}, H^{*}\right)$ satisfies the first-order necessary conditions:

$$
\begin{aligned}
& \frac{\partial \mathcal{L}}{\partial D}(D, H, \lambda)=l . C_{D}{ }^{\prime}(D)+\lambda \frac{\partial F}{\partial D}(D, H, Q)=0 \\
& \frac{\partial \mathcal{L}}{\partial H}(D, H, \lambda)=C_{H}{ }^{\prime}(H)+\lambda \frac{\partial F}{\partial H}(D, H, Q)=0
\end{aligned}
$$

Where, $C_{D}{ }^{\prime}(D)$ (respectively $\left.C_{H}{ }^{\prime}(H)\right)$ is the marginal annual cost of the pipeline (respectively of the compressor station). Note that a straightforward property of that optimal combination of pipeline

\footnotetext{
${ }^{4}$ With the functional forms chosen in his 2008 article, Dr. Yépez notes that the second-order conditions for the existence and uniqueness of a minimum are satisfied.
} 
diameter and horsepower of the compressor station $\left(D_{L R}^{*}, H_{L R}^{*}\right)$ can be exhibited. These two firstorder conditions imply that the optimum combination $\left(D_{L R}^{*}, H_{L R}^{*}\right)$ satisfies:

$$
\frac{l . C_{D}\left(D_{L R}^{*}\right)}{C_{H}\left(H_{L R}^{*}\right)}=\frac{\frac{\partial F}{\partial D}\left(D_{L R}^{*}, H_{L R}^{*}, Q\right)}{\frac{\partial F}{\partial H}\left(D_{L R}^{*}, H_{L R}^{*}, Q\right)}
$$

\section{A remark on the annual costs of the line and of the compressor station}

The specifications chosen for the annual costs functions $C_{D}(D)$ and $C_{H}(H)$ clearly constitute one of the noteworthy differences between Chenery (1949) and Yépez (2008). As it will be shown below, these specifications play a non-negligible role on the economics of the cost function in both short and long-run. Thus, they deserve a short comment.

Chenery used only linear specifications with constant linear coefficients, a choice that he justified as follows: "Although theoretically these parameters may be functions of the indicated engineering variables, the available data show them to be practically constant over the range which has been experienced in practice." (Chenery, 1949, p. 518). In his contribution, Dr. Yépez preferred concave functional forms for $C_{D}(D)$ and $C_{H}(H)$, a choice that he justified with an empirical argument based on the result of a personal investigation. Regarding that empirical section, a representative econometrician could regret the absence of some of the classical attributes of a typical empirical study: a basic description of the data (source, number of observations, etc.) and a discussion on the regression results (t-statistics, $\mathrm{R}^{2}$, etc.)... Nevertheless, the intrinsic importance of this remark can be toned down since publicly available information on cost data for that industry is rather scarce. Given Dr Yépez's position, his estimates can be viewed as reliable and up-to-date sources. Thus, it is almost certain that many practitioners and/or gas economists prefer his publicly available results to many a lesser man's studies.

\section{Scale economies, some empirical evidences}

In his discussion on the long-run economics of the natural gas transportation industry, Dr. Yépez noticed the presence of significant economies of scale. His affirmation is inspired by the shape of the long-run cost curves as both long-run average cost (LRAC) and long-run marginal cost (LRMC) are decreasing and the former exceeds the later. In his conclusion, he rightly underlined that this result has important implications for the design of appropriate pricing policies, since applying a long-run marginal-cost pricing do not allow the industry to break even. 
To complete this plot-inspired remark, some additional results may be useful to quantify those scale economies. In another papers dedicated to investment issues, Pr. Chenery suggested that the long-run cost function of the gas pipeline has almost constant elasticity of output with respect to cost over most of its range (Chenery, 1952). Thus, the function $\gamma Q^{1 / \psi}$, where $\psi$ represents a scale coefficient ${ }^{5}$ and $\gamma$ a constant, could provide an acceptable approximation of the long-run total annual cost function $\operatorname{LRTC}(Q)$. Given that Dr. Yépez's analysis differs from Pr. Chenery (as it includes a modernized version of the technological relations and a non-linear specification for the inputs costs $C_{D}(D)$ and $C_{H}(H)$ ), the validity of this approximation needs to be validated with a statistical approach.

In this empirical sub-section, data are generated from the industry process model and depict the longrun total cost for various quantities. Based on these "pseudo data", simple relationships such as those suggested by Pr. Chenery can be statistically estimated. In fact, this method has its roots in Pr. Griffin's set of studies published in the 1970's (Griffin, 1977, 1978, 1979). At that time, available computational technologies prohibited the direct inclusion of cumbersome process models in large inter-industry simulation and forecasting models. The "pseudo data" approach was seen as a computational-friendly tool able to simplify these complex engineering models into single equation cost function.

In the present study, a data set of 84 observations was generated by running several instances of Dr. Yépez's model with the list of parameters presented in Appendix 1. In these numerical simulations, the output varied from 0.25 to $21 \mathrm{Bcm} /$ year (billions cubic meter of gas per year) - i.e: 25.6 to 2147.5 MMcfd - by regular steps of $0.25 \mathrm{Bcm} /$ year. Here, cost data are thus drawn over a sufficiently wide range that represents usual operation conditions in the natural gas transmission industry. Thanks to the usual log transformation, an Ordinary Least Square (OLS) regression was performed to estimate Chenery's specification. Table 1 presents the empirical results for this statistical cost function.

Table 1: Empirical results obtained from an OLS regression on Chenery's specification. The numbers in parentheses are standard errors of coefficients.

\begin{tabular}{|c|cc|}
\hline $\log ($ LRTC $)=\begin{array}{l}12.34312 \\
(0.000984)\end{array}+\begin{array}{l}0.613467 \\
(0.000145)\end{array}$ & $\log (Q)$ \\
\hline $\mathrm{R}^{2}=0.999995 ;$ S.E. of regression $=0.001218$. \\
\hline
\end{tabular}

These results clearly confirm the pertinence of Chenery's suggestion. The goodness of fit measure $\mathrm{R}^{2}$ indicates an excellent explanatory power which is quite unusual for such a simple specification. The estimated values are clearly of significant as the t-statistics suggests that the probabilities attached to

\footnotetext{
${ }^{5}$ For such a cost function, the ratio of average cost to marginal cost is constant and equal to $\psi$.
} 
the real values being 0 are insignificant. Hence, the specification suggested by Pr. Chenery provides an acceptable approximation of the Long Run Total cost function. As far as the long-run scale coefficient $\psi$ is concerned, these results clearly confirm the presence of significant scale economies: for any given output, the Long-Run Average Cost is always 63\% greater that the Long-Run Marginal Cost. This value clearly reinforces the value of Dr. Yépez's conclusion on price setting: a simple tariff set at the long-run marginal cost would systematically induce significant losses.

\subsection{Short-run cost economics}

\section{The Chenery-Yépez approach}

In the short-run, both Yépez (2008) and Chenery (1952) precise that there are some limits on the substitutability between the two factors $D$ and $H$. In fact, pipeline diameter is an indivisible factor whereas continued adjustment of pumping equipment is easy to implement. Moreover, pipe costs are usually significantly greater than compression $\operatorname{costs}^{6}$. As a result, short-run adjustments needed to serve possible additional demand are usually obtained by increasing the compression horsepower while keeping the same pipeline.

For a given pipeline whose diameter is $D$, the engineering production function (1) can be reorganized to get an expression of the compression horsepower $H$ required in the short-run. This required compression horsepower is fully determined by $Q$ the daily flow rate of natural gas to be transported. In microeconomic jargon, this function is nothing but a short-run factor demand function $H=g_{D}(Q)$ where $g_{D}$ is the following function:

$$
g_{D}: Q \mapsto c_{1} Q \cdot\left(\frac{l Q^{2}}{c_{0}^{2} D^{16 / 3}}+1\right)^{\frac{\beta}{2}}-1
$$

As $g_{D}$ is a smooth, strictly increasing and strictly convex function, it is clear that a $100 \%$ increase in the quantity to be transported through a given pipeline requires a more than $100 \%$ increase in the compression horsepower. As it will be shown below, this remark plays an important role to analyze the behaviour of the Short Run Total Cost function $\operatorname{SRTC}(Q)$.

\footnotetext{
${ }^{6}$ For example: in the data set described above, the share of the pipeline-related costs is always greater than $70 \%$ of the longrun total cost.
} 
This approach allowed Dr. Yépez to derive a single variable expression for SRTC the Short-Run

Total Cost function. Here, $\operatorname{SRTC}(Q)$ is the sum of two elements: a fixed pipeline cost l. $_{D}(D)$ and a variable cost function $C_{H}\left(g_{D}(Q)\right)$ the annual cost of the compressor station.

\section{A U-shaped short-run average cost curve}

Dr. Yépez's Figure 2 (Yépez, 2008, p.80) provides an intriguing suggestion. On that figure, a couple of strictly decreasing Short Run Average Cost functions are plotted. All these curves suggest the presence of some scale economies in the short-run cost functions. But it is perilous to derive definitive conclusions from such a graph as curves have only been plotted on a limited range of output. Some complementary remarks are thus needed to discuss the short-run economics because the presence of increasing/decreasing returns to scale in the short-run is, among other factors, heavily influenced by the functional form chosen for $C_{H}(H)$. Depending on that choice, rather different conclusions can be obtained.

There are slight differences in the specifications chosen by Chenery and Yépez that deserves a discussion. When $C_{H}$ is an increasing convex function (which includes the linear specification used in Chenery (1949)), the Short-Run Marginal Cost function $\operatorname{SRMC}(Q)$ will be strictly increasing with respect to output and $\operatorname{SRMC}(Q)$ will always be greater than the short run average variable cost $Q^{-1} C_{H}\left(g_{D}(Q)\right)$. Adding a strictly decreasing positive pipeline average cost $Q^{-1} l \cdot C_{D}(D)$ provides a typical U-shaped curve for the Short Run Average Cost function $\operatorname{SRAC}(Q)$. In that case, there will be an efficient level of production $Q^{*}$ at which the average cost reaches its minimum. Above that particular output, the firm's short-run operations will clearly exhibit decreasing returns to scale.

With the concave specification of $C_{H}(H)$ chosen by Dr. Yépez, the behaviour of the short run cost function is not so clear. As far as the variable cost is concerned, two opposite effects are at work. Firstly, a "pro-decreasing returns to scale" effect may be expected because of the both increasing and convex nature of the short-run conditional factor demand function $H=g_{D}(Q)$. But simultaneously, the concave specification of $C_{H}(H)$ chosen by Dr. Yépez corresponds to a "pro-increasing returns to scale" effect: a $100 \%$ increase in the horsepower capacity $H$ of the system increases the annual compression station cost by only $90.2 \%$ and the operation and maintenance cost by only $45.2 \%$. Hence, predicting the overall effect obtained when composing these two individual effects requires a deeper analysis. 


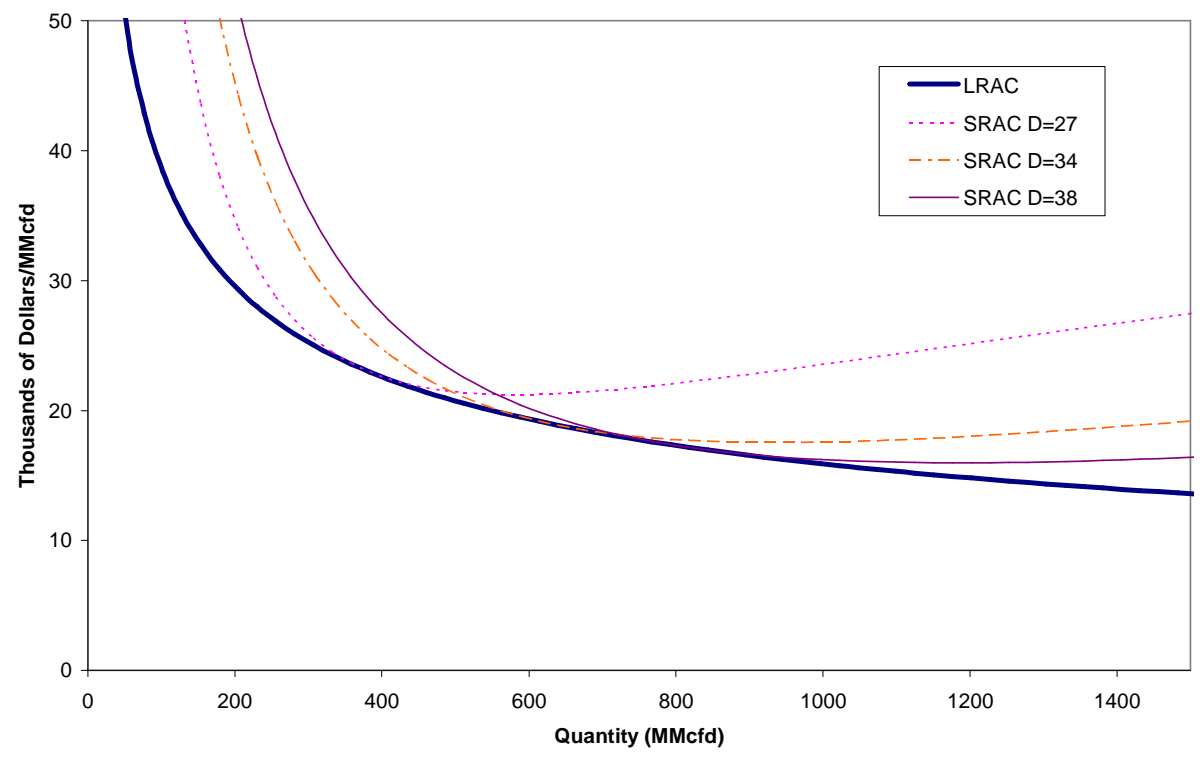

Figure 1: U-shaped Short Run Average Cost curves.

Nevertheless, the short-run average cost function $\operatorname{SRAC}(Q)=\frac{1}{Q}\left(l \cdot C_{D}(D)+C_{H}\left(g_{D}(Q)\right)\right)$ is smooth and defined for all strictly positive output $Q$. With Dr. Yépez's numerical values, it is clear that $\lim _{Q \rightarrow \infty} \operatorname{SRAC}(Q)=+\infty$. Hence, it is clear that the increasing return to scale suggested on Dr. Yépez's Figure 2 (Yépez, 2008, p.80) is a local phenomenon that cannot be generalized to any output. Stated differently, it simply means that with those compression cost parameters, the concavity of $C_{H}(H)$ is not sufficient to counterbalance the "diseconomies of scale" effect induced by the convex nature of the short-run conditional factor demand function $H=g_{D}(Q)$. This finding is consistent with the U-shaped Short Run Average Cost curves obtained from numerical simulations based on Dr. Yépez's numerical values (cf. Figure 1).

As will be discussed below, this finding has important implications when considering the adaptation of any already installed transmission equipment to a significant increase in the planned output.

\section{"Looping" economics, a simple introduction}

An obvious corollary emerges from these U-shaped short run average cost curves. In his paper, Dr. Yépez rightly suggested that the cheapest way to accommodate an additional output in the short run is the addition of compression horsepower. This affirmation clearly holds for small increments in the gas flows. But, is it also the cheapest solution when considering the adaptation needed to serve a very large increment? Even without paying any attention to possible technological restrictions (e.g.: an upper limit on the pipeline's operating pressures), there can exist an economically grounded argument to choose a different solution. A sufficiently large incremental volumes to be transported can lead the transmission firm to operate in the "diseconomies of scale" region. If that increment is large enough, it 
can be worth comparing two alternative solutions: a continued addition of pumping equipment versus laying a second gas transmission line in parallel onto the existing one. In the natural gas industry, this "replication" is quite frequent and is called "looping".

A simple introduction to "looping" economics can be found in Chenery (1952). In that paper, Pr. Chenery studied the simplistic case of a strict replication of the existing line and noted that it pays to duplicate a line when the increment $\Delta Q$ is large enough to get:

$$
\operatorname{SRTC}(Q+\Delta Q) \geq 2 . S R T C\left(\frac{Q+\Delta Q}{2}\right)
$$

If that inequation holds, a solution based on a doubled transmission infrastructure where each pipeline transports one half of the total flow $Q+\Delta Q$ is less costly than those based on a single line design whose total cost is $\operatorname{SRTC}(Q+\Delta Q)$. A similar reasoning is also valid for the transition from two to three lines and so forth. On the assumption that the diameter of pipeline installed remains unchanged, a lower envelope curve can be exhibited. This later curve was named "intertemporal cost curve" by the late Pr. Chenery who noted that it represents the evolution of the total annual cost over time if output always increases on the assumption that the size of unit installed (here, the pipeline diameter) remains unchanged.

Figure 2 provides an illustration in the case of a 100-miles infrastructure that was initially designed to transport a daily flow rate of $383.487 \mathrm{MMcf}$ of natural gas. With the numerical assumptions listed in Appendix 1, the optimal design includes pipe diameter of 27 inches and a compressor of 3,858 hp.

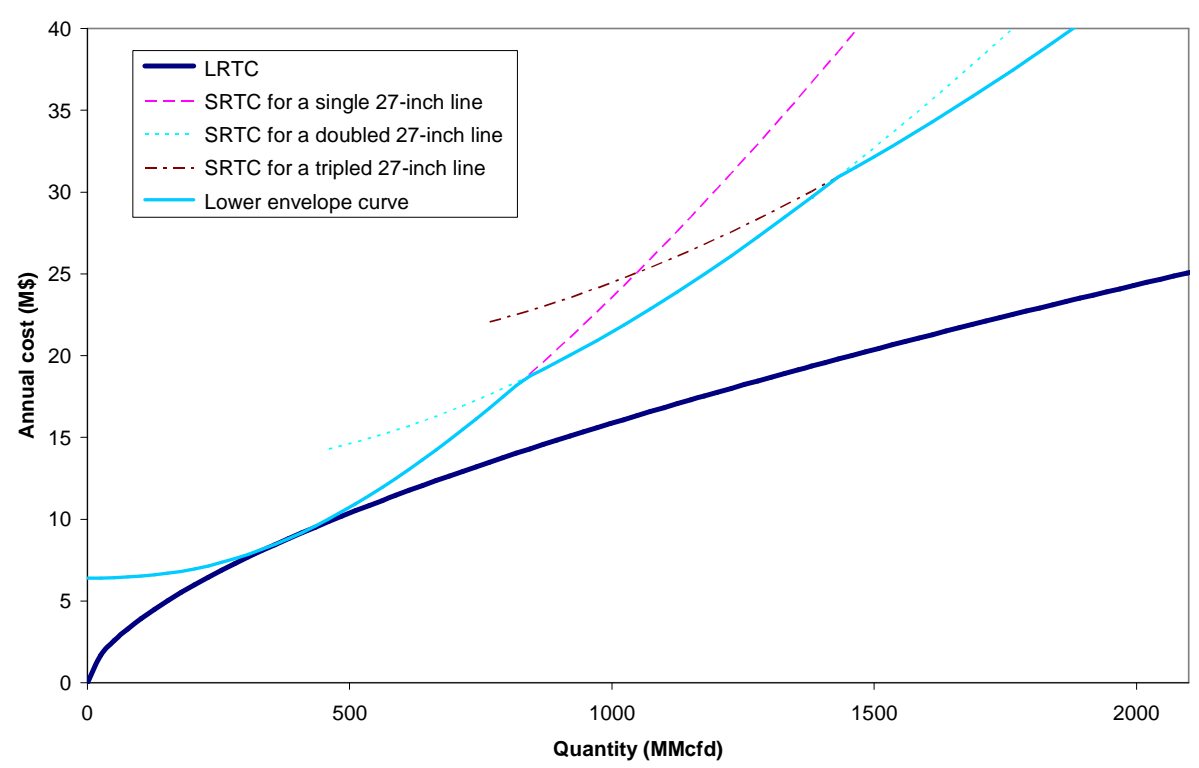

Figure 2: Short-run and intertemporal total cost curves for natural gas pipelines. 
This treatment is based on the simple case of a strict duplication of the pre-existing infrastructure. In real industrial cases, planners are free to choose a different diameter for the new pipeline to be laid. To conclude on looping, it is also interesting to underline that meshed networks are frequent in the gas transmission industry. This feature introduces a significant complexity in the identification of an optimal looping policy (e.g.: Andre et al., 2009). Nevertheless, this straightforward description provides an intuitive introduction to "looping" economics.

\subsection{Long-run vs short-run, an alternative and simplified view}

This section aims at showing that the long-run problem studied by both Chenery and Yépez can be reformulated in a simplified manner.

First, attention is focussed on the role played by pipeline diameter in the short run. Any change in that diameter has a major impact on the short-run economics of the transmission equipment since it changes the repartition of the total cost between fixed costs (pipeline related cost) and outputdependant ones (the compression costs). In a sense, $D$ can be viewed as an index of scale that characterizes the size of a given transmission equipment.

For a given flow of gas to be transported $Q$, the engineering production function (1) can also be reorganized to get the compression horsepower $H$ required in the short-run as a differentiable and strictly decreasing function of the pipeline diameter $D$ (provided that $D$ remains strictly positive) and parameterized by $Q$ the daily flow rate of natural gas to be transported:

$$
f_{Q}: D \mapsto c_{1} Q \cdot\left(\left(\frac{l Q^{2}}{c_{0}^{2} D^{16 / 3}}+1\right)^{\frac{\beta}{2}}-1\right)
$$

The influence of the pipeline diameter $D$ on the Short-Run Total Cost to transport a given flow rate of gas $Q$ is described by the cost function $\operatorname{SRTC}_{Q}(D)=l \cdot C_{D}(D)+C_{H}\left(f_{Q}(D)\right)$, parameterized by $Q$. Obviously, the pipeline element $l . C_{D}(D)$ is usually a strictly increasing function of the pipeline diameter, whereas the annual compression cost $C_{H}\left(f_{Q}(D)\right)$ is strictly decreasing with respect to $D$ because of the technical substitutions mentioned earlier.

A simple reformulation of the long-run cost minimization problem can now be proposed. Each strictly positive value of $D$ corresponds to a unique Short-Run Total Cost function that is parameterized by a continuous parameter: $Q$. Hence, a family of Short-Run Total Cost functions indexed by a continuous variable $D$ can be defined. For a given output $Q$, each of these function provides a short run total 
cost and those values varies with the pipeline diameter $D$. In this subsection, it will be proved that the long-run cost minimization problem can be viewed equivalently as selecting an appropriate (and unique) element in that family of short-run cost curves.

Restated with simple algebra, the goal is to find the particular Short-Run Total Cost function that minimizes the annual cost of transporting a given flow $Q$ of gas. As $D$ is assumed to be a continuous parameter, a necessary condition for minimum annual cost is that the derivative of Short-Run Total Cost with respect to $D$ be zero:

$$
\frac{d S R T C_{Q}}{d D}(D)=0
$$

Equivalently,

$$
\text { l. } C_{D}^{\prime}(D)=-f_{Q}^{\prime}(D) \times C_{H}^{\prime}\left(f_{Q}(D)\right) .
$$

As usual, an economic interpretation can be given to that expression: at the optimum, the marginal cost of the pipeline is exactly equal to the marginal compression horsepower economy.

From a technical perspective, some straightforward arguments can be given to illustrate the existence of a unique solution to equation (4). As $\operatorname{SRTC}_{Q}(D)$ is differentiable with $\lim _{D \rightarrow 0^{+}} S R T C_{Q}(D)=+\infty$ and $\lim _{D \rightarrow+\infty} S R T C_{Q}(D)=+\infty$, it is clear (Rolle's theorem) that there is at least one solution to equation (4). Of course, uniqueness of that solution depends on the functional specifications chosen for both $C_{D}$ and $C_{H}$. With Pr. Chenery's linear specifications, the function $\operatorname{SRTC}_{Q}(D)$ is strictly convex and has thus an unique global minimum. With Dr. Yépez's concave specifications, convexity is no longer verified but the numerical values used in Yépez (2008) insure a U-shaped curve with the succession of two strictly monotonic patterns: a decreasing one and an increasing one. As a result, there is also a unique minimum cost with Dr. Yépez's specification. Hence, the problem at hand is well behaved as both Dr. Yépez's and Pr. Chenery's specifications are consistent with the existence of a unique solution to equation. Let's denote $D_{S R}^{*}$ that solution.

It is now time to compare that solution $D_{S R}^{*}$ with those denoted $\left(D_{L R}^{*}, H_{L R}^{*}\right)$ obtained when solving the long-run cost minimization programme proposed by Chenery and Yépez. Here comes an interesting lemma: 
Lemma 1: Assume a gas transmission firm with costs and engineering production function as described above. For that firm, the long run optimal combination of inputs $\left(D_{L R}^{*}, H_{L R}^{*}\right)$ that solves Dr. Yépez's cost minimizing programme is exactly equal to $\left(D_{S R}^{*}, f_{Q}\left(D_{S R}^{*}\right)\right)$, those obtained with the single variable problem above.

For the interested reader, a straightforward proof of that result is provided in Appendix 2.

Clearly this approach simplifies the long run problem as it only requires solving a single variable equation. In the next sections, that simplification will be helpful to illustrate some new results. On top of that, this very simple approach provides a clear argument for presenting the Long Run Total Cost curve as the lower envelope of the Short Run Total Cost curves. Figure 3 offers an useful illustration of that assertion.

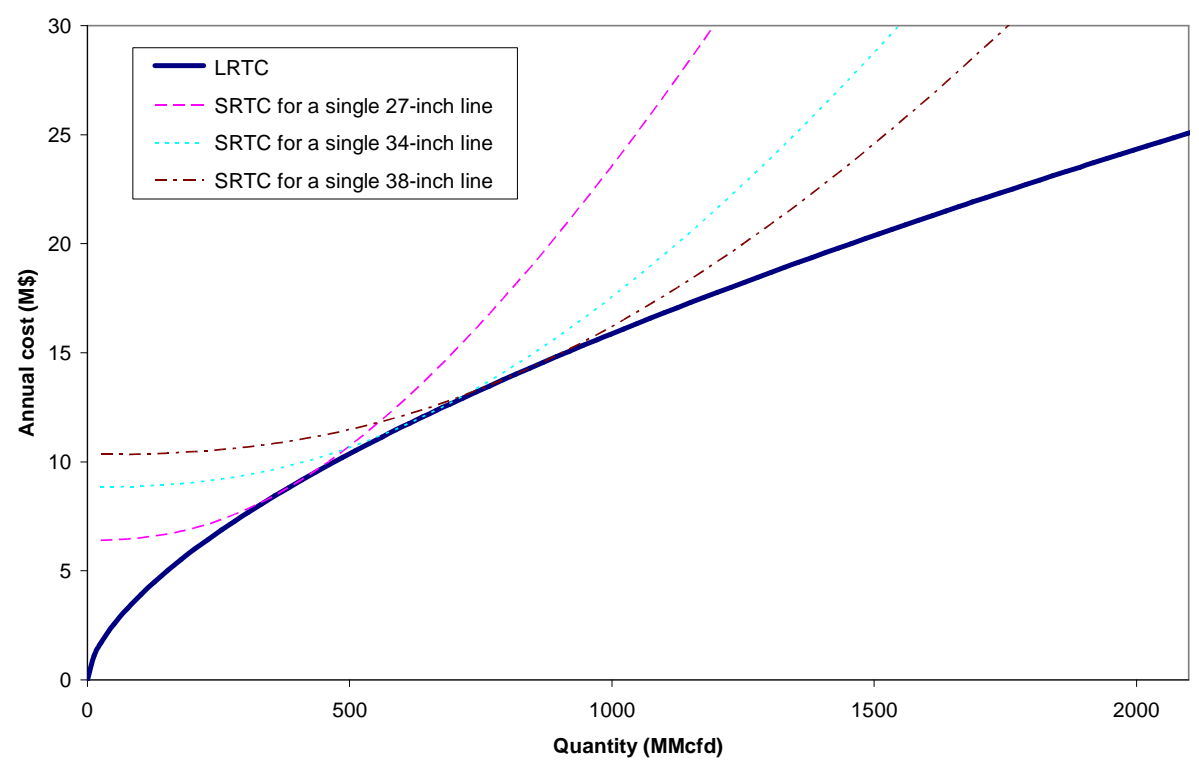

Figure 3: The Long Run Total Cost curve as the lower envelope of the Short Run Total Cost ones.

\section{2 - Dealing with seasonal variations}

In their papers, both Pr. Chenery and Dr. Yépez studied the case of a transmission equipment that is planned to transport a steady flow of natural gas $Q$ all across the year. How is the short-run total annual cost impacted by seasonal changes in that flow-rate? How does this seasonal pattern influence the optimal design of that infrastructure? These are precisely some of the questions addressed in this second section. 


\subsection{A further distinction: expansion vs contraction costs}

This preliminary subsection provides a useful piece of methodological background. Following the usual convention, Dr. Yépez defines the short-run as a period of time in which the quantity of at least one input is fixed (here the diameter $D$ ) and the quantities of the other input $H$ can vary. As in classic microeconomic theory, the long run corresponds to an hypothetical situation in which the quantities of all inputs can vary. Aside from that usual distinction, a further distinction could be valuable to analyze the short-run economics of that industry: that between expansion and contraction costs. That distinction pioneered by the "French marginalist school" relies on the asymmetry between plant expansion and plant contraction since some fixed costs to be incurred in case of expansion cannot be recouped in case of contraction (Cf. Dreze (1964) for a comprehensive survey). In fact, Chenery himself also perceived the pertinence of that further distinction: "The functions resulting from fixing the pipe size (scale of plant) and varying other factors (amount of pumping equipment, etc.) will be called "intermediate" cost functions. It is possible to move along the intermediate cost curves only as long as demand is expanding. A contraction of demand will involve a movement along a "plant" curve (...) where the only important variable is fuel consumption." (Chenery, 1952, p. 4).

Dr. Yépez's framework provides an interesting starting point to implement that distinction in the natural gas industry. On the assumption that the pipeline diameter remains unchanged in the short-run, the output-variable element corresponds to the total annual cost of the compressor stations that includes the capital costs and the operation and maintenance costs. Given that any expansion requires the installation of an additional compression capacity whose annual cost is fully captured in this shortrun cost function, it is clear that Dr. Yépez's short-run total cost function describes the variation of annual cost if output always increases. But in case of a sudden and temporary drop in output, rigidity would probably be observed in the downward adjustment of the compression capacity. Stated differently, it means that there are few chances for such a restriction in output to be accompanied with an instantaneous premature scrapping of the excess in compression capacity.

With those remarks in mind and using the previous notations, a simple reformulation can now be proposed to distinguish expansion and contraction costs. For a gas transmission infrastructure that transports a given flow $Q_{0}$ with a pipeline whose diameter is $D$ and an adapted compression capacity $H_{0}=g_{D}\left(Q_{0}\right)$, the total expansion cost incurred to serve a larger steady flow-rate of natural gas $Q \geq Q_{0}$ is given by Dr Yépez's short-run total cost function $\operatorname{SRTC}(Q)$ that includes the extra capital expenses required for the installation of an additional pumping capacity. In case of a contraction in the output to $Q<Q_{0}$, the annual compression station cost $\alpha_{C} . C_{3}\left(H_{0}\right)$ remains unchanged whereas the operation and maintenance costs are reduced to reflect a lower annual rate of operation of the compressors. As most of these operation and maintenance costs correspond to the cost of the energy 
(gas or electricity) used to drive the compressor, a linear scale down rule can reasonably be posited to model those variations. These costs are thus supposed to vary in proportion to the capacity-utilisation rate $Q / Q_{0}$; here, these variable costs are equal to $\frac{Q}{Q_{0}} C_{4}\left(H_{0}\right)$.

To summarize, the short-run total expansion cost function SRTEC of that infrastructure is given by:

$$
\operatorname{SRTEC}: Q \mapsto \operatorname{SRTC}(Q)=l \cdot C_{D}(D)+\alpha_{C} \cdot C_{3}\left(g_{D}(Q)\right)+C_{4}\left(g_{D}(Q)\right) \quad \forall Q \geq Q_{0}
$$

Whereas the short-run total contraction cost function SRTCC is:

$$
\text { SRTCC: } Q \mapsto l . C_{D}(D)+\alpha_{C} \cdot C_{3}\left(H_{0}\right)+\frac{Q}{Q_{0}} C_{4}\left(H_{0}\right) \quad \forall Q<Q_{0}
$$

Hence, the short-run total cost function takes either one or the other expression depending on whether $Q$ the output to be served, is larger or not than the initial level $Q_{0}$. As far as short-run marginal cost is concerned, we can notice a discontinuity for the particular output $Q=Q_{0}$. For this output, the right derivative, i.e. $\frac{d}{d Q}\left[\alpha_{C} \cdot C_{3}\left(g_{D}(Q)\right)+C_{4}\left(g_{D}(Q)\right)\right]$, gives the marginal expansion cost whereas the left derivative, i.e. $\frac{1}{Q_{0}} C_{4}\left(H_{0}\right)$, corresponds to the marginal contraction cost. Explicit reference must thus be made to one of these concepts when considering practical applications of marginal costs. More generally, the possible non-equality of left-hand and right-hand short-run marginal costs at adapted capacity has already been emphasized in the literature (see for example Pierru (2007) for an economic interpretation in the case of linear-programming models).

\subsection{The case of seasonal variations}

Obviously, gas consumption varies over time - across seasons, weeks and days. Moreover, the amplitude of these variations can be large. A typical illustration is provided by the seasonal swing observed in countries where natural gas is largely used for heating. As an example, in north-western Europe approximately two-thirds of the gas is consumed during the winter period (October-March). Moreover, "residential users consume about 90 percent of their overall gas during the winter period. For local gas providers, it is therefore not uncommon to have daily peaks in gas delivery in the winter amounting to more than ten times the delivery on a summer day." (Höffler and Kübler, 2007, pp. 5206-5207). In many cases, gas cannot be stored near end-users. Significant seasonal fluctuations can 
thus be observed in the daily flows of gas to be transported. For a transmission infrastructure, such a situation results in an average daily output that is strictly smaller than the peak flow.

To analyze the influence of these seasonal variations, we study the case of a rational firm that plans to build an equipment to transport time-varying gas flows. The firm is supposed to know precisely: $q_{t}$ the daily flow of gas demanded on day $t$, and $Q_{p}$ the peak flow to be transported on that infrastructure (i.e. : $Q_{p}=\operatorname{Max}_{t} q_{t}$ ). A one year periodicity is assumed for the gas flows (i.e.: $\left.q_{t}=q_{t+365}\right)$. The average daily flow rate to be observed during a particular year is denoted $\bar{q}$. A strictly less than one load factor is also assumed for that infrastructure, which means that $\bar{q}<Q_{p}$ (the case of a $100 \%$ load factor corresponds to the steady flow case studied by both Chenery and Yépez).

Here again the firm's decision can be analyzed as an annual cost minimization problem. As in the Chenery-Yépez approach, the problem faced by the firm can be viewed as a cost-minimization programme:

$$
\begin{array}{lll}
\underset{D, H_{p},\left\{H_{t}\right\}_{t}}{\operatorname{Min}} & l . C_{D}(D)+\alpha_{C} \cdot C_{3}\left(H_{p}\right)+\frac{\bar{q}}{Q_{p}} \cdot C_{4}\left(H_{p}\right) \\
\text { s.t. } & F\left(D, H_{t}, q_{t}\right)=0 & \forall t \in\{1, \ldots, 365\} \\
& H_{t} \leq H_{p} & \forall t \in\{1, \ldots, 365\}
\end{array}
$$

The objective is to minimize the annual total cost incurred to transport the daily flows $\left(q_{t}\right)_{t \in\{1, \ldots, 365\}}$ with an equipment whose compressor station has a capacity $H_{p}$ and whose pipeline has a internal diameter $D$. Of course, $H_{p}$ must imperatively be large enough to provide any of the compression horsepower $\left\{H_{t}=f_{q_{t}}(D)\right\}_{t \in\{1, \ldots, 365\}}$. Given that the model at hand is fully deterministic, there is no incentive to build any extra capacity and the compression capacity to be installed is thus supposed to be equal to the minimum required to serve those peak flow $Q_{p}$. Hence, the peak compression horsepower $H_{p}$ is given by $f_{Q_{p}}(D)$.

Here again, this problem can be reformulated as a single variable optimization programme: i.e. finding the unique optimal diameter $D_{\bar{q}, Q_{p}}^{*}$ that minimizes the short-run total contraction cost function 
SRTCC to serve the average daily flow $\bar{q}$ knowing that this infrastructure must be capable to supply the peak output $Q_{p}$, i.e. $H_{p}=f_{Q_{p}}\left(D_{\bar{q}, Q_{p}}^{*}\right)$.

The optimal pipeline design, denoted $D_{\bar{q}, Q_{p}}^{*}$, minimizes the following annual cost function $\operatorname{SRTCC}_{\bar{q}, Q_{p}}: D \mapsto l \cdot C_{D}(D)+\alpha_{C} \cdot C_{3}\left(f_{Q_{p}}(D)\right)+\frac{\bar{q}}{Q_{p}} C_{4}\left(f_{Q_{p}}(D)\right)$. A necessary condition is that the derivative of that cost function with respect to pipeline diameter $D$ be zero:

$$
\frac{d \operatorname{SRTCC}_{\bar{q}, Q_{p}}}{d D}\left(D_{\bar{q}, Q_{p}}^{*}\right)=0
$$

As usual, that condition has its economic interpretation. At that optimum, the marginal increase in the pipeline cost is exactly equal to the marginal compression cost reduction.

As a benchmark, it is interesting to compare this optimal pipeline diameter $D_{q_{,}, Q_{p}}^{*}$ with those, denoted $D_{Q_{p}}^{*}$, that would have been chosen if the firm had to transport a steady flow $Q_{p}$. As the infrastructure must be designed to transport the peak flow $Q_{p}$, each of the two following combinations of inputs $\left(D_{\bar{q}, Q_{p}}^{*}, f_{Q_{p}}\left(D_{\bar{q}, Q_{p}}^{*}\right)\right)$ and $\left(D_{Q_{p}}^{*}, f_{Q_{p}}\left(D_{Q_{p}}^{*}\right)\right)$ represents a technology-compatible choice.

\section{Proposition 1:}

Assume a gas transmission firm with a seasonal-varying output, costs and engineering production function as described above. For that firm, the long run optimal combination of input $\left(D_{\bar{q}, Q_{p}}^{*}, f_{Q_{p}}\left(D_{\bar{q}, Q_{p}}^{*}\right)\right)$ involves a smaller diameter and a larger horsepower capacity than those that would have been installed to serve a steady daily flow equal to the peak value $Q_{p}$.

Again, a straightforward proof of that result is provided in Appendix 2.

This result is rational: a lower load factor creates an incentive to lower the transportation cost by preferring a mix of inputs that includes more compressor horsepower (that generates flexibility) and less pipeline. 


\section{3 - Building ahead the demand, an irrational decision?}

This section provides a discussion on the optimal investment policies that can be derived from the Chenery-Yépez approach. In his discussion on the economics of the natural gas transportation industry, Dr. Yépez suggests that: "Whatever the planned level of output, the rational firm will select a transportation system whose short-run average total cost is tangent to its LRAC at that capacity" (Yépez, 2008, p. 80). It is tempting to confront this rule with the investment decisions actually taken in the gas industry.

\subsection{Preliminary remarks}

Evidences drawn from the gas industry provides numerous cases of transmission infrastructures that were designed with a significantly oversized diameter. The "Yamal pipeline" - an impressive 56inches diameter infrastructure that runs from the Yamal peninsula (northern Russia) to Germany across Belarus and Poland - provides an archetypal example. Since its construction in the end-1980's, the gas flow transported on that infrastructure has never exceeded $20 \mathrm{Bcm} / \mathrm{y}$, which is a relatively low figure compared to the initial plans (Victor and Victor, 2006). Another case is given by the contemporary Nabucco project, a large gas transmission infrastructure that has been proposed for construction across the South-East Europe and Turkey to carry gas from the Caspian region to Austria and other European markets. The design chosen for this project involves a large diameter (56-inches) that looks considerably oversized for the expected flow $(8 \mathrm{Bcm} / \mathrm{y})$. In both cases, a cost-minimizing design based on the Chenery-Yépez approach would certainly suggest a smaller diameter/compression horsepower ratio. Why did the teams of skilled and experienced planners who designed those infrastructures preferred alternative solutions based on larger diameters?

This question calls for a closer examination of the model's hypotheses. More precisely, the planned infrastructure is designed to transport a steady flow $Q$ whose value is known and expected to remain steady during the whole project's life. This assumption allows analyzing the decision in a static and deterministic framework. In the previous industrial cases, this important condition was not fulfilled. For the "Yamal pipeline", the initial plan was based on the construction of two parallel 56-inch pipelines allowing an export potential of $67 \mathrm{Bcm} / \mathrm{y}$. By now, only one of these two pipelines has been built with a reduced number of compressors from the original plan (Victor and Victor, 2006). As far as Nabucco is concerned, a phased design has also been adopted. It relies on a single large-diameter pipeline with a compression capacity initially adjusted to transport $8 \mathrm{Bcm} / \mathrm{y}$ during the first phase. Then, continued additions of compression capacity will ultimately allow increasing its output to 31 $\mathrm{Bcm} / \mathrm{y}$, a large flow that justifies a 56-inches diameter. In both cases, planner's decision to use an oversized pipeline diameter reflected the perceived massive - but uncertain when the pipeline design was decided - exports perspectives to the European gas markets. Stated differently, planners explicitly 
take into consideration the possibility to have significant, but still uncertain, expansions in the flows that will be transported during the infrastructure's lifetime.

\subsection{Overcapacity, an irrational decision?}

The aim of this subsection is to propose a simple extension of the Chenery-Yépez framework to take into consideration the remarks above; hence, to analyze the rationality of such a "building ahead the demand" behaviour. This discussion echoes the so-called capacity expansion problem studied in economic theory, a field also pioneered by H.B. Chenery. In his seminal contribution, Chenery (1952) discussed the effect of technology on investment behaviour with the goal to illustrate how the simultaneous presence of growing demand and economies of scale may motivate the construction of an oversized equipment. Stated differently, Pr. Chenery proved that "a building ahead the demand" decision can be rational. Following that contribution, the optimal degree of excess capacity to be built into a new facility has motivated an admirable stream of literature with a noteworthy extension provided in Manne (1961) that analyzed the case of a random-walk pattern of trends in demand (see Luss (1982) for a complete survey).

In this subsection, a simple framework is used to analyze whether that "building ahead the demand" behaviour can be observed in the gas transmission industry. For expository reasons, a simple discrete time context will be used (extension to continuous version is straightforward). To do so, I focus on the case of a firm that, at date $t=0$, is considering the construction of a single-line transportation infrastructure that is expected to transport a given steady daily flow of gas $Q_{0}$ over a predefined planning horizon of $Y$ years. Given the long durability of gas transmission equipments, it is assumed that there will be no equipment replacements during that period.

Compared to the previous models, we now consider the case of a possible future expansion of the output. Hence, there is a known date $T, T \in\{1, \ldots, Y\}$ at the beginning of which the possible output expansion will be decided or not. The decision outcome is still uncertain but is assumed to be restricted to two cases: either a sudden output expansion to a known value $Q_{1}$, with $Q_{1}>Q_{0}$; or a status quo to $Q_{0}$. The probability to observe a rise to $Q_{1}$ is denoted $p$.

If such an additional output was to be decided, the cheapest way to accommodate that additional flow would be the addition of compression horsepower. Hence, the planner's set of decision variables can be restricted to three elements: the pipeline diameter $D$, the initial compressor horsepower $H_{0}$ required to move $Q_{0}$, and the compressor horsepower $H_{1}$ that could eventually be needed to transport $Q_{1}$ from date $T$ to $Y$. 
As previously, $\operatorname{LRTC}\left(D, H_{0}\right)=l \cdot C_{D}(D)+C_{H}\left(H_{0}\right)$ is the annual total cost of an equipment designed to transport a steady daily flow $Q_{0}$ during the predefined planning horizon $Y$. Besides, planners have to take into consideration a possible extra compression cost in case of an output expansion. It is assumed that the increased horsepower $H_{1}$ can be obtained by installing, at the beginning of year $T$, more compressors in addition to the existing ones at a cost $C_{3}\left(H_{1}\right)-C_{3}\left(H_{0}\right)$. Clearly, these new compressors will only be used during $Y-T$.

Evaluated at year $T$, the annual equivalent extra-cost required to install and operate these new compressors during $Y-T$ is denoted $\Delta C\left(H_{0}, H_{1}\right)$ and is equal to:

$$
\Delta C\left(H_{0}, H_{1}\right)=\alpha_{\Delta H} \cdot\left[C_{3}\left(H_{1}\right)-C_{3}\left(H_{0}\right)\right]+C_{4}\left(H_{1}\right)-C_{4}\left(H_{0}\right)
$$

where $\alpha_{\Delta H}$ is the fixed-cost annual percentage charge dependent on the depreciation and real interest rates to operate those additional compressors during $Y-T$. In fact, $\alpha_{\Delta H}$ is obtained by computing the constant annual outlay stream that has an expected present value equal to that of all future cost outlay over the horizon $Y-T$. In most real cases, we have $\alpha_{\Delta H}>\alpha_{H}$.

A risk-neutral planner is supposed to minimize the expected total annual cost of that infrastructure $\bar{C}\left(D, H_{0}, H_{1}\right)$ subject to the usual engineering equations:

$$
\begin{array}{ll}
\operatorname{Min}_{D, H_{0}, H_{1}} & \bar{C}\left(D, H_{0}, H_{1}\right)=\operatorname{LRTC}\left(D, H_{0}\right)+p \cdot \frac{1}{(1+r)^{T}} \Delta C\left(H_{0}, H_{1}\right) \\
\text { s.t. } & F\left(D, H_{0}, Q_{0}\right)=0 \\
& F\left(D, H_{1}, Q_{1}\right)=0
\end{array}
$$

Using the previous modus operandi, this problem can easily be rearranged into a single-variable objective function to be minimized. In fact, the optimal pipeline diameter computed for a probability $p$ is called $D_{p}^{*}$ and must minimize the expected total annual cost function:

$$
\bar{C}: D \mapsto \bar{C}\left(D, f_{Q_{0}}(D), f_{Q_{1}}(D)\right)
$$

With the functional specifications chosen by Dr. Yépez, this function has a unique minimum which is the only point where the derivative of that function with respect to pipeline diameter $D$ is equal to zero . Thus, a necessary (and in that case sufficient) condition for a minimum is: 


$$
\frac{d \bar{C}}{d D}\left(D_{p}^{*}\right)=0
$$

That condition has its economic interpretation: at the optimal diameter the marginal increase in the pipeline cost is exactly equal to the expected marginal reduction in compression cost.

As a benchmark, a planner could find interesting to confront that outcome with the optimal diameter $D_{0}^{*}$ that would have been selected in case of a zero probability for the sudden net increase in output.

\section{Proposition 2:}

Assume a gas transmission firm with a probability $p$ for an sudden rise in its output at date $T$, with costs and engineering production function as described above. For that firm, the long run optimal combination of equipments to be installed at date $t=0$ involves a pipeline diameter $D_{p}^{*}$ that is larger than those, denoted $D_{0}^{*}$ that would have been installed by a planner that do not take into consideration this possible future rise in output.

Again, a straightforward proof of that result is provided in Appendix 2.

In many countries, the level of prices charged by gas transmission firms is subject to public control and this result has important implications for the design of appropriate regulatory policies. In many cases, a rate of return regulation is implemented. This form of regulation sees costs as exogenous and observable and forms prices on the basis of observed costs and appropriate rate of return on capital. One of the principal criticisms that has arisen for this kind of regulation is based on the so-called Averch-Johnson effect. According to Averch and Johnson (1962), the profit seeking behaviour of the regulated firm subject to rate of return regulation induces a distortion in the input choice: the optimal choice of that firm is not the cost minimising one. More precisely, the capital/labour ratio chosen by the firm subject to rate of return regulation is greater than the cost minimising capital/labour ratio for the given the level of output. Obviously, such a statement calls for a condemnation of the tendency of regulated firms to engage in excessive amounts of durable capital accumulation to expand the volume of their profits. The previous proposition suggests a rather different explanation for the firm's preference for a capital intensive technology. Here, the firm's decision to choose an input mix that includes a larger diameter/horsepower ratio (in economist's jargon: a greater capital/energy ratio) is completely independent of the regulatory environment, such a choice is entirely motivated by an anticipation of possible future output expansion.

\section{Conclusions}

Throughout this article the cost functions for the natural gas transmission industry presented in Chenery (1949) and Yépez (2008) are discussed in the light of some the key features of that industry. 
A commented review of the Chenery-Yépez methodology has enabled the derivation of some interesting insights such as an empirical quantification of the scale economies encountered in that industry and an economic analysis of "looping". Moreover, two notable extensions have been provided to deal with the case of a seasonal varying output and with those of an uncertain future output expansion. All these results have important implications for the design of appropriate regulatory policies in that industry.

In the vein of Chenery (1949) and Yépez (2008), the technical representation of the gas transmission industry used in this paper remains simple: a radial infrastructure that transports an unidirectional flow of gas over a given distance. In many countries, the development of the natural gas industry came with the construction of a large meshed transmission network and the optimal operation of these infrastructures offers a stimulating field of research for the operations research community (e.g.: Hansen et al., 1991; André et al., 2009). Nevertheless, the Chenery-Yépez method has a great merit: it offers a simple engineering-based approximation of the cost functions encountered in the natural gas transmission industry. For this reason, it is worth being considered as a valuable tool to get a better understanding of the gas pipeline economics. Moreover, it provides an useful complement to the purely statistical approach in the determination of production, cost, and factor demand relationships. A tribute must thus be paid to the late H.B. Chenery for his inspiring work.

\section{References}

Andre, J., Bonnans, F. and L. Cornibert. (2009) Optimization of Capacity Expansion Planning for Gas Transportation Networks. European Journal of Operational Research, 197(3), 1019-1027.

Averch, H. and L. L. Johnson (1962) Behavior of the Firm Under Regulatory Constraint. The American Economic Review, 52(5), 1052-1069.

Callen, J. L. (1978) Production, Efficiency, and Welfare in the Natural Gas Transmission Industry, The American Economic Review, 68(3), 311-323.

Chenery, H. B. (1949) Engineering production functions. The Quarterly Journal of Economics, 63(4), 507-531.

Chenery, H. B. (1952) Overcapacity and the Acceleration Principle Overcapacity and the Acceleration Principle, Econometrica, 20(1), 1-28

Dreze J. H. (1964) Some Post-war Contributions of French Economists to Theory and Public Policy: With Special Emphasis on Problems of Resource Allocation. The American Economic Review, 54(4), 2-64.

Griffin J. M. (1977) Long-run Production Modelling With Pseudo-data: Electric Power Generation, The Bell Journal of Economics, 8(1), 112-27.

Griffin J. M. (1978) Joint Production Technology: The Case of Petrochemicals, Econometrica, 46(2), 379-96.

Griffin J. M. (1979) Statistical Cost Analysis Revisited, The Quarterly Journal of Economics, 93(1), $107-29$. 
Hansen C.T., K. Madsen and H.B. Nielsen (1991) Optimization of pipe networks, Mathematical Programming, 52(11), 45-58.

Höffler F. and M. Kübler (2007) Demand for Storage of Natural Gas in North-Western Europe: Trends 2005-30. Energy Policy, 35(10), 5206-5219.

Luss H. (1982) Operations Research and Capacity Expansion Problems: A Survey. Operations Research, 30(5), 907-947.

Manne A.S. (1961) Capacity Expansion and Probabilistic Growth. Econometrica, 29(4), 632-649.

Pierru A., (2007) Short-run and long-run marginal costs of joint products in linear programming. Louvain Economic Review, 73, 153-171.

Ruan, Y., Q., Liu, W., Zhou, B., Batty, W., Gao, J, Ren and T., Watanabe (2009) A procedure to design the mainline system in natural gas networks. Applied Mathematical Modelling, 33(7), 30403051.

Smith, V.L. (1957) Engineering Data and Statistical Techniques in the Analysis of Production and Technological Change: Fuel Requirements of the Trucking Industry. Econometrica, 25(2), 281-301.

Smith, V.L. (1959) The Theory of Investment and Production. Quarterly Journal of Economics, 73(1), 61-87.

Thompson, R. G., Proctor, M.S. and R. R. Hocking (1972) Investment-Borrowing Decisions in Natural Gas Transmission Investment-Borrowing Decisions in Natural Gas Transmission. Management Science, 18(10) Application Series, B544-B554.

Victor N. and D.G. Victor, 2006. Bypassing Ukraine: exporting Russian gas to Poland and Germany. In Victor, D.G., Jaffe, A.M., Hayes, M. H. (Eds), Natural Gas and Geopolitics: From 1970 to 2040, Cambridge University Press; 2006.

Yépez R. A. (2008) A cost function for the natural gas industry. The Engineering Economist, 53(1), 68-83. 


\section{APPENDIX 1}

All the numerical simulations presented in this paper are entirely based on the following assumptions chosen for an hypothetical 100-miles long project ( $l=100$ miles). The technical specifications for the gas are exactly those used in Yépez (2008):

\begin{tabular}{|l|c|}
\hline$T_{b}$ base temperature & $520 \circ \mathrm{R}$ \\
\hline$T$ mean flowing temperature & $535 \circ \mathrm{R}$ \\
\hline$P_{b}$ base pressure & $14.73 \mathrm{psia}$ \\
\hline$P_{1}$ initial pressure in the pipe & $1070 \mathrm{psia}$ \\
\hline$P_{2}$ terminal pressure in the pipe & $838 \mathrm{psia}$ \\
\hline$G$ gas specific gravity for the gas in the region & 0.62 \\
\hline$Z$ compressibility factor & 0.8835 \\
\hline$\beta$ dimensionless constant & 0.22178 \\
\hline
\end{tabular}

Hence, the dimensionless constants have the following values: $c_{0}=0.742$ and $c_{1}=183.2$ (Yépez, 2008). The annual cost parameters (in US Dollars) are also those presented in Yépez (2008):

$$
\begin{aligned}
& \alpha_{L} \cdot C_{1}(D, \tau)=7144.59 D^{0.881} \tau^{0.559} ; \\
& C_{2}(D)=317.61 D^{0.809} ; \\
& \alpha_{C} \cdot C_{3}(H)=1256.33 H^{0.9016} ; \\
& C_{4}(H)=6145.177 H^{0.4523}
\end{aligned}
$$

Moreover, the pipe thickness $\tau$ is assumed to be a linear function of $D$ the inside diameter: $\tau=\frac{D}{110}$.

This formulation has been suggested by stability of pipe concerns (cf. Ruan et al., 2009, p. 3044). Hence, the annual cost of the line per mile is $\alpha_{L} \cdot C_{1}(D)=\frac{7144.59}{110^{0.559}} D^{0.881+0.559}$.

\section{APPENDIX 2}

\section{Proof of Lemma 1:}

For a given flow of gas to be transported $Q$, it is clear that $\operatorname{SRTC}_{Q}\left(D_{S R}^{*}\right) \geq \operatorname{LRTC}\left(D_{L R}^{*}, H_{L R}^{*}\right)$ (otherwise, there would be an obvious contradiction with $\left(D_{L R}^{*}, H_{L R}^{*}\right)$ being the unique optimal solution to the programme (2) as the combination $\left(D_{S R}^{*}, f_{Q}\left(D_{S R}^{*}\right)\right)$ would provide a lower cost). We now have to prove that $\operatorname{SRTC}_{Q}\left(D_{S R}^{*}\right)=\operatorname{LRTC}\left(D_{L R}^{*}, H_{L R}^{*}\right)$. As a textbook example of a reductio ad absurdum, we assume that $\operatorname{SRTC}_{Q}\left(D_{S R}^{*}\right)>\operatorname{LRTC}\left(D_{L R}^{*}, H_{L R}^{*}\right)$ and have a closer look at the solution 
$\left(D_{L R}^{*}, H_{L R}^{*}\right)$. As that solution imperatively satisfies the engineering equation (1), we have a relation between $D_{L R}^{*}$ and $H_{L R}^{*}: H_{L R}^{*}=f_{Q}\left(D_{L R}^{*},\right)$. Hence, $\operatorname{SRTC}_{Q}\left(D_{S R}^{*}\right)>\operatorname{LRTC}\left(D_{L R}^{*}, H_{L R}^{*}\right)$ corresponds to $\operatorname{SRTC}_{Q}\left(D_{S R}^{*}\right)>\operatorname{L} \cdot C_{D}\left(D_{L R}^{*}\right)+C_{H}\left(f_{Q}\left(D_{L R}^{*}\right)\right)$. Given that the right-hand side of that equation is nothing but $\operatorname{SRTC}_{Q}\left(D_{L R}^{*}\right)$, we have a obvious contradiction with $D_{S R}^{*}$ being the unique diameter that minimizes the Short Run Total Cost to transport $Q$.

Q.E.D.

\section{Proof of Proposition 1:}

The short run total cost to transport an average daily flow $\bar{q}$ on a transmission infrastructure designed to transport a peak output $Q_{p}$ is given by:

$$
\operatorname{SRTCC}_{\bar{q}, Q_{p}}(D)=\operatorname{SRTC}_{Q_{p}}(D)-\left(1-\frac{\bar{q}}{Q_{p}}\right) \cdot C_{4}\left(f_{Q_{p}}(D)\right)
$$

where $\operatorname{SRTC}_{Q_{p}}(D)$ is the function described previously that gives the short-run total cost to transport a steady flow $Q_{p}$ and $\operatorname{SRTCC}_{\bar{q}, Q_{p}}(D)$ is the short-run total contraction cost. The derivative of that second function with respect to $D$ is equal to:

$$
\frac{d S R T C C_{\bar{q}, Q_{p}}}{d D}(D)=\frac{d S R T C_{Q_{p}}}{d D}(D)-\left(1-\frac{\bar{q}}{Q_{p}}\right) \cdot f_{Q_{p}}^{\prime}(D) \cdot \frac{d C_{4}}{d D}\left(f_{Q_{p}}(D)\right)
$$

As the diameter $D_{Q_{p}}^{*}$ satisfies condition (5), we have:

$$
\frac{d \operatorname{SRTCC}_{\bar{q}, Q_{p}}}{d D}\left(D_{Q_{p}}^{*}\right)=-\left(1-\frac{\bar{q}}{Q_{p}}\right) \cdot f_{Q_{p}}^{\prime}\left(D_{Q_{p}}^{*}\right) \cdot \frac{d C_{4}}{d D}\left(f_{Q_{p}}\left(D_{Q_{p}}^{*}\right)\right)
$$

Since $f_{Q_{p}}$ is a strictly decreasing function and $C_{4}$ is an increasing one, the right-hand side of this equation is strictly positive which means that the short-run total contraction cost is locally strictly increasing with $D$ in the neighbourhood of the particular diameter $D_{Q_{p}}^{*}$. Given that $S R T C C_{\bar{q}, Q_{p}}$ is a differentiable function with a unique minimum, it indicates that the optimal diameter $D_{q, Q_{p}}^{*}$ is on the left of $D_{Q_{p}}^{*}$ which means that $D_{q, Q_{p}}^{*}<D_{Q_{p}}^{*}$. Thus, a gas transmission firms that serves a fluctuating 
demand (i.e. $\bar{q}<Q_{p}$ ) prefers to choose a mix of inputs $\left(D_{\bar{q}, Q_{p}}^{*}, f_{Q_{p}}\left(D_{\bar{q}, Q_{p}}^{*}\right)\right)$ based on a smaller diameter and a larger compression capacity than those chosen in case of a steady demand equal to $Q_{p}$, i.e.: $\left(D_{Q_{p}}^{*}, f_{Q_{p}}\left(D_{Q_{p}}^{*}\right)\right)$.

Q.E.D.

\section{Proof of Proposition 2:}

As in the proof of Proposition 1, the sketch of proof relies on an evaluation of the sign of the derivative of the expected total annual cost function with respect to pipeline diameter $D$ evaluated for the particular diameter $D_{0}^{*}$. As $\bar{C}$ is a smooth function with a unique minimum, this information allows to conclude on the relative size of $D_{0}^{*}$ and $D_{p}^{*}$ because a negative (conversely positive) value clearly suggests that $D_{0}^{*}<D_{p}^{*}$ (conversely $D_{0}^{*}>D_{p}^{*}$ ).

$D_{0}^{*}$ satisfies condition (8) in the particular case of $p=0$. In case of $p>0$, the derivative of $\bar{C}$ with respect to $D$ is equal to:

$$
\frac{d \bar{C}}{d D}\left(D_{0}^{*}\right)=p \cdot \frac{1}{(1+r)^{T}} \cdot \frac{d}{d D} \Delta C\left(f_{Q_{0}}\left(D_{0}^{*}\right), f_{Q_{1}}\left(D_{0}^{*}\right)\right)
$$

Hence, we have to study the sign of the derivative of $\Delta C\left(f_{Q_{0}}(D), f_{Q_{1}}(D)\right)$ with respect to $D$. As $\Delta C\left(H_{0}, H_{1}\right)=\alpha_{\Delta H} \cdot\left[C_{3}\left(H_{1}\right)-C_{3}\left(H_{0}\right)\right]+C_{4}\left(H_{1}\right)-C_{4}\left(H_{0}\right)$ it can be sufficient to prove that the derivative of $C_{3}\left(f_{Q_{1}}(D)\right)-C_{3}\left(f_{Q_{0}}(D)\right)$ and those of $C_{4}\left(f_{Q_{1}}\left(D_{0}^{*}\right)\right)-C_{4}\left(f_{Q_{0}}\left(D_{0}^{*}\right)\right)$ are both negative.

Let's start with the increment capital cost the compressors $\omega: D \mapsto C_{3}\left(f_{Q_{1}}(D)\right)-C_{3}\left(f_{Q_{0}}(D)\right)$ and analyze its gradient on $D=D_{0}^{*}$ :

$$
\frac{d \omega}{d D}\left(D_{0}^{*}\right)=f_{Q_{1}}^{\prime}\left(D_{0}^{*}\right) \times C_{3}^{\prime}\left(f_{Q_{1}}\left(D_{0}^{*}\right)\right)-f_{Q_{0}}^{\prime}\left(D_{0}^{*}\right) \times C_{3}^{\prime}\left(f_{Q_{0}}\left(D_{0}^{*}\right)\right)
$$

With the engineering relation at hand, it is clear that pipeline and compression are two substitutes: any increase in the pipeline diameter reduces the horsepower capacity required to move the gas. Hence, both $f_{Q_{1}}^{\prime}\left(D_{0}^{*}\right)$ and $f_{Q_{0}}^{\prime}\left(D_{0}^{*}\right)$ are strictly negative which gives: 


$$
\frac{d \omega}{d D}\left(D_{0}^{*}\right)=-\left[\left|f_{Q_{1}}^{\prime}\left(D_{0}^{*}\right)\right| \times C_{3}^{\prime}\left(f_{Q_{1}}\left(D_{0}^{*}\right)\right)-\left|f_{Q_{0}}^{\prime}\left(D_{0}^{*}\right)\right| \times C_{3}^{\prime}\left(f_{Q_{0}}\left(D_{0}^{*}\right)\right)\right]
$$

Let us have a look at the sign of $f_{Q_{1}}^{\prime}\left(D_{0}^{*}\right)-f_{Q_{0}}^{\prime}\left(D_{0}^{*}\right)$. At this stage, it is worth studying the influence of the parameter $Q$ on $f_{Q}^{\prime}(D)$. A quick study of the function:

$$
h: Q \mapsto f_{Q}^{\prime}(D)=\frac{-16}{3 D} \frac{\beta}{2} c_{1} \frac{\theta \cdot Q^{3}}{\left(\theta \cdot Q^{2}+1\right)^{1-\frac{\beta}{2}}} \text { where } \theta=\frac{l}{c_{0}^{2} D^{16 / 3}}
$$

provides the required information. With usual numerical values $(0<\beta<2)$, this function is strictly decreasing. Hence, $f_{Q_{1}}^{\prime}\left(D_{0}^{*}\right)<f_{Q_{0}}^{\prime}\left(D_{0}^{*}\right)<0$, hence $\left|f_{Q_{1}}^{\prime}\left(D_{0}^{*}\right)\right|-\left|f_{Q_{0}}^{\prime}\left(D_{0}^{*}\right)\right|>0$.

With Dr. Yépez's strictly concave and increasing specification for $C_{3}$, we have $C_{3}^{\prime}\left(f_{Q_{0}}\left(D_{0}^{*}\right)\right)>C_{3}^{\prime}\left(f_{Q_{1}}\left(D_{0}^{*}\right)\right)>0$.

As a result:

$$
\left|f_{Q_{1}}^{\prime}\left(D_{0}^{*}\right)\right| \times C_{3}^{\prime}\left(f_{Q_{1}}\left(D_{0}^{*}\right)\right)-\left|f_{Q_{0}}^{\prime}\left(D_{0}^{*}\right)\right| \times C_{3}^{\prime}\left(f_{Q_{0}}\left(D_{0}^{*}\right)\right)>\left(\left|f_{Q_{1}}^{\prime}\left(D_{0}^{*}\right)\right|-\left|f_{Q_{0}}^{\prime}\left(D_{0}^{*}\right)\right|\right) \times C_{3}^{\prime}\left(f_{Q_{0}}\left(D_{0}^{*}\right)\right)
$$

As the right-hand side is strictly positive, we have: $\frac{d \omega}{d D}\left(D_{0}^{*}\right)<0$.

As $C_{4}$ is also a smooth concave functions, a similar line of reasoning can also be applied to show that the derivative of $C_{4}\left(f_{Q_{1}}\left(D_{0}^{*}\right)\right)-C_{4}\left(f_{Q_{0}}\left(D_{0}^{*}\right)\right)$ with respect to $D$ is also strictly negative.

As a result, we have: $\frac{d \bar{C}}{d D}\left(D_{0}^{*}\right)<0$.

Q.E.D. 


\section{Déjà parus}

CEG-1. D. PERRUCHET, J.-P. CUEILLE,

Compagnies pétrolières internationales : intégration verticale et niveau de risque.

Novembre 1990

\section{CEG-2. C. BARRET, P. CHOLLET,}

Canadian gas exports: modeling a market in disequilibrium.

Juin 1990

CEG-3. J.-P. FAVENNEC, V. PREVOT,

Raffinage et environnement.

Janvier 1991

\section{CEG-4. D. BABUSIAUX,}

Note sur le choix des investissements en présence de rationnement du capital.

Janvier 1990

\section{CEG-5. J.-L. KARNIK,}

Les résultats financiers des sociétés de raffinage distribution en France 1978-89.

Mars 1991

\section{CEG-6. I. CADORET, P. RENOU,}

Élasticités et substitutions énergétiques : difficultés méthodologiques.

Avril 1991

\section{CEG-7. I. CADORET, J.-L. KARNIK,}

Modélisation de la demande de gaz naturel dans le secteur domestique : France, Italie, Royaume-Uni 19781989.

Juillet 1991

\section{CEG-8. J.-M. BREUIL,}

Émissions de SO2 dans l'industrie française : une approche technico-économique.

Septembre 1991

CEG-9. A. FAUVEAU, P. CHOLLET, F. LANTZ,

Changements structurels dans un modèle économétrique de demande de carburant.

Octobre 1991

\section{CEG-10. P. RENOU,}

Modélisation des substitutions énergétiques dans les pays de l'OCDE.

Décembre 1991

\section{CEG-11. E. DELAFOSSE,}

Marchés gaziers du Sud-Est asiatique : évolutions et enseignements.

Juin 1992

\section{CEG-12. F. LANTZ, C. IOANNIDIS,}

Analysis of the French gasoline market since the deregulation of prices.

Juillet 1992

\section{CEG-13. K. FAID,}

Analysis of the American oil futures market.

Décembre 1992

\section{CEG-14. S. NACHET,}

La réglementation internationale pour la prévention et l'indemnisation des pollutions maritimes par les hydrocarbures.

Mars 1993 


\section{CEG-15. J.-L. KARNIK, R. BAKER, D. PERRUCHET,}

Les compagnies pétrolières : 1973-1993, vingt ans après.

Juillet 1993

\section{CEG-16. N. ALBA-SAUNAL,}

Environnement et élasticités de substitution dans l'industrie ; méthodes et interrogations pour l'avenir.

Septembre 1993

\section{CEG-17. E. DELAFOSSE,}

Pays en développement et enjeux gaziers : prendre en compte les contraintes d'accès aux ressources locales. Octobre 1993

\section{CEG-18. J.P. FAVENNEC, D. BABUSIAUX,*}

L'industrie du raffinage dans le Golfe arabe, en Asie et en Europe : comparaison et interdépendance.

Octobre 1993

\section{CEG-19. S. FURLAN,}

L'apport de la théorie économique à la définition d'externalité.

Juin 1994

\section{CEG-20. M. CADREN,}

Analyse économétrique de l'intégration européenne des produits pétroliers : le marché du diesel en Allemagne et en France.

Novembre 1994

\section{CEG-21. J.L. KARNIK, J. MASSERON,*}

L'impact du progrès technique sur l'industrie du pétrole.

Janvier 1995

CEG-22. J.P. FAVENNEC, D. BABUSIAUX,

L'avenir de l'industrie du raffinage.

Janvier 1995

CEG-23. D. BABUSIAUX, S. YAFIL,*

Relations entre taux de rentabilité interne et taux de rendement comptable. Mai 1995

CEG-24. D. BABUSIAUX, J. JAYLET,*

Calculs de rentabilité et mode de financement des investissements, vers une nouvelle méthode? Juin 1996

CEG-25. J.P. CUEILLE, J. MASSERON,*

Coûts de production des énergies fossiles : situation actuelle et perspectives. Juillet 1996

CEG-26. J.P. CUEILLE, E. JOURDAIN,

Réductions des externalités : impacts du progrès technique et de l'amélioration de l'efficacité énergétique. Janvier 1997

CEG-27. J.P. CUEILLE, E. DOS SANTOS,

Approche évolutionniste de la compétitivité des activités amont de la filière pétrolière dans une perspective de long terme.

Février 1997

CEG-28. C. BAUDOUIN, J.P. FAVENNEC, Marges et perspectives du raffinage. Avril 1997 
CEG-29. P. COUSSY, S. FURLAN, E. JOURDAIN, G. LANDRIEU, J.V. SPADARO, A. RABL, Tentative d'évaluation monétaire des coûts externes liés à la pollution automobile : difficultés méthodologiques et étude de cas.

Février 1998

CEG-30. J.P. INDJEHAGOPIAN, F. LANTZ, V. SIMON,

Dynamique des prix sur le marché des fiouls domestiques en Europe.

Octobre 1998

CEG-31. A. PIERRU, A. MAURO,

Actions et obligations : des options qui s'ignorent.

Janvier 1999

CEG-32. V. LEPEZ, G. MANDONNET,

Problèmes de robustesse dans l'estimation des réserves ultimes de pétrole conventionnel.

Mars 1999

CEG-33. J. P. FA VENNEC, P. COPINSCHI,

L'amont pétrolier en Afrique de l'Ouest, état des lieux

Octobre 1999

CEG-34. D. BABUSIAUX,

Mondialisation et formes de concurrence sur les grands marchés de matières premières énergétiques : le pétrole.

Novembre 1999

CEG-35. D. RILEY,

The Euro

Février 2000

CEG-36. et 36bis. D. BABUSIAUX, A. PIERRU, ${ }^{*}$

Calculs de rentabilité et mode de financement des projets d'investissements : propositions méthodologiques. Avril 2000 et septembre 2000

CEG-37. P. ALBA, O. RECH,

Peut-on améliorer les prévisions énergétiques ?

Mai 2000

CEG-38. J.P. FAVENNEC, D. BABUSIAUX,

Quel futur pour le prix du brut?

Septembre 2000

ECO-39. S. JUAN, F. LANTZ,

La mise en œuvre des techniques de Bootstrap pour la prévision économétrique : application à l'industrie automobile

Novembre 2000

ECO-40. A. PIERRU, D. BABUSIAUX,

Coût du capital et étude de rentabilité d'investissement : une formulation unique de l'ensemble des méthodes.

Novembre 2000

ECO-41. D. BABUSIAUX,

Les émissions de $\mathrm{CO} 2$ en raffinerie et leur affectation aux différents produits finis

Décembre 2000

ECO-42. D. BABUSIAUX,

Éléments pour l'analyse des évolutions des prix du brut.

Décembre 2000 


\section{ECO-43. P. COPINSCHI,}

Stratégie des acteurs sur la scène pétrolière africaine (golfe de Guinée).

Janvier 2001

\section{ECO-44. V. LEPEZ,}

Modélisation de la distribution de la taille des champs d'un système pétrolier, LogNormale ou Fractale ?

Une approche unificatrice.

Janvier 2001

ECO-45. S. BARREAU,

Innovations et stratégie de croissance externe : Le cas des entreprises parapétrolières.

Juin 2001

ECO-46. J. P. CUEILLE,

Les groupes pétroliers en 2000 : analyse de leur situation financière.*

Septembre 2001

\section{ECO-47. T. CAVATORTA,}

La libéralisation du secteur électrique de l'Union européenne et son impact sur la nouvelle organisation électrique française

Décembre 2001

\section{ECO-48. P. ALBA, O. RECH,}

Contribution à l'élaboration des scénarios énergétiques.

Décembre 2001

ECO-49. A. PIERRU,*

Extension d'un théorème de dualité en programmation linéaire : Application à la décomposition de coûts marginaux de long terme.

Avril 2002

\section{ECO-50. T. CAVATORTA,}

La seconde phase de libéralisation des marchés du gaz de l'Union européenne : enjeux et risques pour le secteur gazier français.

Novembre 2002

ECO-51. J.P. CUEILLE, L. DE CASTRO PINTO COUTHINO, J. F. DE MIGUEL RODRÍGUEZ,*

Les principales compagnies pétrolières indépendantes américaines : caractéristiques et résultats récents.

Novembre 2002

ECO-52. J.P. FAVENNEC,

Géopolitique du pétrole au début du XXI ${ }^{\mathrm{e}}$ siècle

Janvier 2003

ECO-53. V. RODRIGUEZ-PADILLA, avec la collaboration de T. CAVATORTA et J.P. FAVENNEC,*

L'ouverture de l'exploration et de la production de gaz naturel au Mexique, libéralisme ou nationalisme Janvier 2003

ECO-54. T. CAVATORTA, M. SCHENCKERY,

Les majors pétroliers vers le multi énergies : mythe ou réalité ? Juin 2003

ECO-55. P.R. BAUQUIS, *

Quelles énergies pour les transports au XXI ${ }^{e}$ siècle?

Janvier 2004 


\section{ECO-56. A. PIERRU, D. BABUSIAUX,}

Evaluation de projets d'investissement par une firme multinationale : généralisation du concept de coût moyen pondéré du capital et conséquences sur la valeur de la firme.

Février 2004

ECO-57. N. BRET-ROUZAUT, M. THOM,

Technology Strategy in the Upstream Petroleum Supply Chain.

Mars 2005

ECO-58. A. PIERRU,

Allocating the $\mathrm{CO}_{2}$ emissions of an oil refinery with Aumann-Shapley prices.

June 2005

ECO-59. F. LESCAROUX,

Les conséquences économiques de la hausse du prix du pétrole.*

Mai 2006

ECO-60. F. LESCAROUX, O. RECH

L'origine des disparités de demande de carburant dans l'espace et le temps : l'effet de la saturation de l'équipement en automobiles sur l'élasticité revenu.

Juin 2006

ECO-61. C. I. VASQUEZ JOSSE, A. NEUMANN,

Transatlantic Natural Gas Price and Oil Price Relationships - An Empirical Analysis. Septembre 2006

ECO-62. E. HACHE,

Une analyse de la stratégie des compagnies pétrolières internationales entre 1999 et 2004.

Juillet 2006

\section{ECO-63 F. BERNARD, A. PRIEUR,}

Biofuel market and carbon modeling to evaluate French biofuel policy.

Octobre 2006

\section{ECO-64. E. HACHE,}

Que font les compagnies pétrolières internationales de leurs profits ?

Janvier 2007

ECO-65. A. PIERRU,

A note on the valuation of subsidized Loans - Working paper

Janvier 2007

\section{ECO-66. D. BABUSIAUX, P. R. BAUQUIS,*}

Que penser de la raréfaction des ressources pétrolières et de l'évolution du prix du brut?

Septembre 2007

\section{ECO-67. F. LESCAROUX,}

Car ownership in relation to income distribution and consumers's spending decisions.

Novembre 2007

\section{ECO-68. D. BABUSIAUX, A. PIERRU,}

Short-run and long-run marginal costs of joint products in linear programming Juin 2008

\section{ECO-69. E. HACHE,}

Commodities Markets: New paradigm or new fashion?

Juillet 2008 


\section{ECO-70. D.BABUSIAUX, A. PIERRU,}

Investment project valuation: A new equity perspective

Février 2009

\section{ECO-71. O. MASSOL, S. TCHUNG-MING}

Stratégies coopératives dans l'industrie du GNL : l'argument de la rationalisation est-il fondé ? Février 2009

\section{ECO-72. A. PIERRU, D.BABUSIAUX,}

Valuation of investment projects by an international oil company: A new proof of a straightforward, rigorous method

Février 2009

\section{ECO-73. E. SENTENAC CHEMIN}

Is the price effect on fuel consumption symmetric? Some evidence from an empirical study. Avril 2009

\section{ECO-74. E. HACHE}

Obama : vers un green new deal énergétique?

Septembre 2009

* une version anglaise de cet article est disponible sur demande 